\title{
HUBUNGAN POLA KONSUMSI MAKANAN TINGGI PURIN TERHADAP KEKAMBUHAN GOUT ARTRITIS DI POLI KLINIK PENYAKIT DALAM RS PERTAMEDIKA UMMI ROSNATI BANDA ACEH
}

\author{
Alfina Ansyarullah'1, Edy Cahyady², Zurriyani² \\ ${ }^{1}$ Mahasiswa Kedokteran, Fakultas Kedokteran, Universitas Abulyatama, Aceh \\ ${ }^{2}$ Dosen Fakultas Kedokteran, Universitas Abulyatama, Aceh
}

\begin{abstract}
Relationship of High Purine Food Consumption Patterns Against Gout Arthritis Recurrence at Ummi Rosnati Hospital's Pertamedika Banda Aceh. Gout is a degenerative disease which greatly disrupts quality of life. The number of gout patients tends to increase and most belong to the productive age group and the elderly. The type and amount of food can be a cause of diagnosed gout. Consumption of high purine foods is one of the risk factors for recurrence of gouty arthritis. Methodthis research is a qualitative study using an analytic observational method and a cross sectional approach with a sample of 35 respondents. The sample selection technique uses total sampling with a data collection tool in the form of a high purine food pattern questionnaire and frequency of pain recurrence. Data analysis using chi square test.Results from the results of the study found 6 people $(17.14 \%)$ who have a good diet and rarely experience recurrence of gouty arthritis. Of the 29 people $(82.9 \%)$ who had poor diets, 8 respondents $(22.85 \%)$ experienced rarely a relapse of pain and 21 respondents $(60.01 \%)$ often experienced a relapse. From the results of data analysis, the value of $P$ value $=0.005(a=0.05)$ means that $\mathrm{Ho}$ is rejected and $\mathrm{Ha}$ is accepted. This shows that there is a relationship between high purine food consumption with gout arthritis recurrence. Conclusion The results of the study indicate the importance of education about setting a good high purine dietary pattern for gout patients to prevent the occurrence of gouty arthritis.
\end{abstract}

Keywords :Food Patterns, High Purin Consumption, Gout Recurrence

\begin{abstract}
Abstrak:Hubungan Pola Konsumsi Makanan Purin Tinggi Terhadap Kekambuhan Artritis Gout di Rumah Sakit Ummi Rosnati Pertamedika Banda Aceh.Penyakit gout merupakan penyakit degeneratif yang sangat mengganggu kualitas hidup. Jumlah pasien gout cenderung meningkat dan kebanyakan tergolong pada kelompok usia produktif. Jenis dan jumlah makanan dapat menjadi salah satu penyebab terdiagnosis gout.Konsumsi makanan tinggi purin merupakan salah satu faktor resiko terhadap kekambuhan gout artritis. Metode penelitian ini merupakan penelitian kuantitatif dengan menggunakan metode observasional analitik dan pendekatan secara cross sectional dengan sampel yang terdiri dari 35 responden. Teknik pemilihan sampel menggunakan total sampling dengan alat pengumpul data berupa kuesioner pola makanan tinggi purin dan frekuensi kekambuhan nyeri. Analisis data menggunakan uji chi square. Hasil dari hasil penelitian didapatkan 6 orang $(17,14 \%)$ yang memiliki pola makan baik dan jarang mengalami kekambuhan gout artritis. Dari 29 orang $(82,9 \%)$ yang memiliki pola makan buruk, 8 responden ( $22,85 \%)$ mengalami jarang kekambuhan nyeri dan 21 responden $(60,01 \%)$ sering mengalami kekambuhan. Dari hasil analisis data didapatkan nilai $P$ value $=0,005$ $(a=0,05)$ yang berarti Ho ditolak dan Ha diterima. Hal ini menunjukan bahwa ada hubungan antara konsumsi makanan tinggi purin dengan kekambuhan gout artritis. Kesimpulan hasil penelitian mengindikasikan pentingnya edukasi tentang pengaturan
\end{abstract}


pola makanan tinggi purin yang baik terhadap pasien gout untuk mencegah terjadinya kekambuhan gout artritis.

Kata Kunci :Pola Makan, Konsumsi Purin tinggi, Kekambuhan Gout

\section{PENDAHULUAN}

Gout artritis merupakan penyakit gangguan metabolik yang ditandai dengan meningkatnya kadar asam urat didalam darah (hiperurisemia). Melebihi $7,0 \mathrm{mg} / \mathrm{dl}$ pada pria dan $6,0 \mathrm{mg} / \mathrm{dl}$ pada wanita. Apabila kadar asam urat yang terlalu tinggi dibiarkan dalam jangka waktu yang lama, tubuh tidak akan mampu mempertahankan homeostasis, keadaan ini sangat mempermudah terbentuknya kristal monosodium urat pada sendi. kristal monosodium urat juga bisa mengendap di jaringan tulang rawan, tendon, ginjal dan jaringan lain yang akan menimbulkan reaksi peradangan(Sumariyono dan Alwi, 2018).

Berdasarkan data dari American College of Rheumatology pada tahun 2015 terjadi peningkatan prevalensi kejadian gout artritis di setiap negara yang ada di dunia mencapai 3,9\% di Amerika Serikat, 0,9\% di Perancis, 1,4$2,5 \%$ di Inggris , $1.4 \%$ di Jerman(Neogi et al., 2015). Berdasarkan Chinese Medical Journal tahun 2017 prevalensi gout di China mengalami peningkatan selama 10 tahun ini. prevalensinya berkisar 5,46\% hingga 19,30\%(Mei et al., 2017).

Berdasarkan

Perhimpunan

Reumatologi Indonesia tahun 2018 gout mengenai $1-2 \%$ populasi dewasa dan merupakan kasus artritis inflamasi terbanyak pada pria(Sumariyono dan Alwi, 2018). Prevalensi penyakit gout diperkirakan 13,6 per 1000 pria dan 6,4 per 1000 wanita, pada pria asam urat meningkat pada masa pubertas, dan puncak onset gout artritis pada usia 4060 tahun. Sedangkan wanita, kadar asam urat meningkat pada saat menopause, dan puncak onsetnya pada usia 60-80 tahun. Namun gout artritis dapat terjadi lebih awal apabila memiliki predisposisi genetik dan memiliki beberapa faktor risiko terjadinya gout artritis (Widyanto, 2017).

Serangan gout berhubungan dengan peningkatan produksi asam urat yang disebabkan oleh usia lanjut, genetik, obesitas serta konsumsi makanan tinggi purin yang berlebih selain itu penyakit gout juga berhubungan dengan penurunan ekskresi asam yang disebabkan oleh konsumsi alkohol berlebih, kurangnya aktivitas fisik, hipertensi dan penyakit jantung obatobatan diuretik (hidroklorotiazide) dan obat antihipertensi lainya serta gangguan fungsi ginjal(Price et al., 2006).

Asam urat sendiri merupakan produk akhir dari metabolisme purin yaitu salah satu komponen asam nukleat yang terdapat dalam inti sel makhluk hidup.Konsumsi makanan tinggi purin secara berlebih merupakan salah satu faktor utama terjadinya gout artritis dan bangkitnya kekambuhan gout. Hal ini disebabkan karena purin merupakan mikroprotein yang terkandung di dalam makanan(Metabolism, 2012).

Berdasarkan prevalensi yang selalu meningkat dan seringnya terjadi kekambuhan gout artritis, terutama pada pasien yang sering mengkonsumsi makanan tinggi purin. Oleh karena itu peneliti ingin mengetahui hubungan pola konsumsi makanan tinggi purin terhadap kekambuhan gout artritis.

\section{METODE}

Penelitian ini merupakan penelitian observasi analitik dengan desain penelitian Cross sectional.Populasi penelitian ini adalah seluruh pasien gout artritis yang telah ditegakkan diagnosis 
di poliklinik penyakit dalam RS Pertamedika Ummi Rosnati Banda Aceh.

Sampel penelitian ini diambil secara non probability sampling dengan metode total samplingdengan total responden 35 orang. Variabel independen meliputi pola konsumsi makanan tinggi purin, sedangkan variabel dependen yaitu kekambuhan gout artritis Pada penelitian ini peneliti menggunakan pengumpulan data secara primer dan sekunder.Data primer dilakukan ketika diagnosis gout artritis ditegakan oleh dokter pada saat itu,sementra peneliti mengisi kuesioner melalui wawancara untuk mengumpulkan data. Sedangkan data sekunder dikumpulkan melalui rekam medis yang dibacakan oleh dokter dan peneliti melakukan pengumpulan data dengan mengisi kuesioner melalui wawancara langsung pada pasien untuk mengumpulkan data. Penelitian ini dilakukan di poliklinik penyakit dalam RS Pertamedika Ummi Rosnati Banda Aceh Yang akan dilaksanakan pada januari s/d Maret 2020. Pengolahan data yang diperoleh dari hasil ini diolah secara manual dengan mengelompokan hasil observasi kemudian dilakukan hasil perhitungan skor dan dianalisis menggunakan uji statistik. Data dianalisis menggunakan analisis univariat dan bivariat, analisis univariat untuk melihat distribusi dan frekuensi variabel independen dan dependen, dan analisis bivariat untuk mengetahui hubungan antara variabel pola konsumsi makanan tinggi purin dengan variabel kekambuhan gout artritis yang dianalisis menggunakan uji Chi-Sqaure dengan nilai $a=0,05$ denga ketentuan yang berlaku yaitu bila $p$ value $\leq$ a maka ada hubungan yang bermakna antara variabel independent dan variabel dependen. Bila $p$ value $\geq a$ maka tidak ada hubungan yang bermakna antara variabel independen dan variabel dependen.

HASIL

Tabel 1.Karakteristik responden berdasarkan umur

\begin{tabular}{ccc}
\hline Umur & Frekuensi & Presentase \\
\hline $21-30$ tahun & 1 & $2,9 \%$ \\
$31-40$ tahun & 7 & $20,0 \%$ \\
$41-50$ tahun & 8 & $22,9 \%$ \\
$51-60$ tahun & 13 & $37,1 \%$ \\
$61-70$ tahun & 6 & $17,1 \%$ \\
\hline Jumlah & $\mathbf{3 5}$ & $\mathbf{1 0 0} \%$ \\
\hline
\end{tabular}

Berdasarkan hasil tabel 1. sementara umur tertua terdapat pada menunjukkan bahwa distribusi responden rentan usia 61-70 tahun. berdasarkan umur rata-rata responden berada pada rentan usia 51-60 tahun,

Tabel 2.Karakteristik responden berdasarkan jenis kelamin, pendidikan terakhir, penghasilan dan pekerjaan

\begin{tabular}{cccc}
\hline \multicolumn{2}{c}{ Karakteristik Responden } & Frekuensi & Presentase \\
\hline Jenis Kelamin & & 18 & \\
& Laki - Laki & 17 & $51,4 \%$ \\
Perempuan & $48,6 \%$ \\
\hline
\end{tabular}




\begin{tabular}{|c|c|c|}
\hline Jumlah & 35 & $100 \%$ \\
\hline \multicolumn{3}{|l|}{ PendidikanTerakhir } \\
\hline Tidak sekolah & 0 & $0 \%$ \\
\hline SD & 7 & $20,0 \%$ \\
\hline SMP & 5 & $14,3 \%$ \\
\hline SMA & 13 & $37,1 \%$ \\
\hline Perguruan Tinggi & 10 & $28,6 \%$ \\
\hline Jumlah & 35 & $100 \%$ \\
\hline \multicolumn{3}{|l|}{ Penghasilan } \\
\hline$\leq 2.900 .000 /$ bulan & 20 & $57,1 \%$ \\
\hline$>2.900 .000 /$ bulan & 14 & $40,0 \%$ \\
\hline TidakBerpenghasilan & 1 & $2,9 \%$ \\
\hline Jumlah & 35 & $100 \%$ \\
\hline \multicolumn{3}{|l|}{ Pekerjaan } \\
\hline Ibu Rumah Tangga & 12 & $34,3 \%$ \\
\hline Petani & 6 & $17,1 \%$ \\
\hline Buruh & 1 & $2,9 \%$ \\
\hline Wiraswasta & 7 & $20,0 \%$ \\
\hline Pegawai Swasta & 2 & $5,7 \%$ \\
\hline PNS & 5 & $14,3 \%$ \\
\hline Lain-lain & 2 & $5,7 \%$ \\
\hline Jumlah & 35 & $100 \%$ \\
\hline
\end{tabular}

Berdasarkan hasil tabel 2 distribusi karakteristik responden berdasarkan jenis kelamin, sebagian besar responden adalah laki-laki yaitu sebanyak 18 responden (51,4\%). Berdasarkan tingkat pendidikan terakhir, yang tergolong dalam kategori pendidikan rendah (tidak sekolah, SD, dan SMP ) sebanyak 12 responden
(34,3\%). Berdasarkan penghasilan tiap bulannya, sebagian besar responden berpenghasilan tiap bulannya, $\leq 2.900 .000$ / bulan, sebanyak 20 responden (57,1\%). Dalam hal pekerjaan, responden terbanyak pada kelompok ibu rumah tangga yaitu 12 responden $(34,3 \%)$.

Tabel 3.Distribusi responden berdasarkan pola konsumsi makanan tinggi purin pasien gout di Poliklinik Penyakit Dalam Rumah Sakit Pertamedika Ummi Rosnati Banda Aceh.

Pola Makan

\begin{tabular}{cc}
\hline Baik & 6 \\
Buruk & 29 \\
\hline Jumlah & 35
\end{tabular}
Frekuensi 6 29

\section{Presentase}

$17,1 \%$

$82,9 \%$
Berdasarkan tabel 3 responden memiliki pola makan baik apabila konsumsi makanan tinggi purin tidak lebih dari 1050 mg/minggu, sementara responden yang memiliki pola makan buruk apabila mengkonsumsi makanan tinggi purin lebih dari $1050 \mathrm{mg} / \mathrm{ming} g u$ dapat diketahui bahwa responden yang memiliki pola makan baik yaitu 6 responden $(17,1 \%)$ dan responden yang memiliki pola makan buruk 29 responden $(82,9 \%)$. 
Tabel 4.Distribusi responden berdasarkan frekuensi kekambuhan gout di Poliklinik Penyakit Dalam Rumah Sakit Pertamedika Ummi Rosnati Banda Aceh.

\begin{tabular}{ccc}
\hline $\begin{array}{c}\text { Frekuensi Kekamuhan } \\
\text { Nyeri }\end{array}$ & Frekuensi & Presentase \\
\hline Sering & 21 & $60,0 \%$ \\
Jarang & 14 & $40,0 \%$ \\
\hline Jumlah & $\mathbf{3 5}$ & $\mathbf{1 0 0} \%$ \\
\hline
\end{tabular}

Berdasarkan tabel 4 dapat lebih banyak dibandingkan responden diketahui bahwa proporsi responden yang jarang mengalami kekambuhan yang sering mengalami kekambuhan nyeri 14 orang responden $(40,0 \%)$. nyeri yaitu 21 orang $(60,0 \%)$ responden

Tabel 5. Hubungan Pola Konsumsi Makanan Tinggi Purin dengan Frekuensi Kekambuhan Gout

\begin{tabular}{|c|c|c|c|c|c|c|c|}
\hline \multirow{3}{*}{ Pola Makan } & \multicolumn{7}{|c|}{ Frekuensi Kekambuhan } \\
\hline & \multicolumn{2}{|c|}{ Jarang } & \multicolumn{2}{|c|}{ Sering } & \multicolumn{2}{|c|}{ Total } & P Value \\
\hline & $\mathrm{F}$ & $\%$ & $\mathrm{~F}$ & $\%$ & $\mathrm{~F}$ & $\%$ & \multirow{4}{*}{0,001} \\
\hline Baik & 6 & $100 \%$ & 0 & $100 \%$ & 6 & $100 \%$ & \\
\hline Buruk & 8 & $27,6 \%$ & 21 & $72,4 \%$ & 29 & $100 \%$ & \\
\hline Total & 14 & $40,0 \%$ & 21 & $60,0 \%$ & 35 & $100 \%$ & \\
\hline
\end{tabular}

Berdasarkan tabel 5 menunjukkan bahwa dari 6 responden yang memiliki pola makan yang baik, 6 orang $(17,14 \%)$ jarang mengalami kekambuhan nyeri dan tidak ada responden yang sering mengalami kekambuhan. Dari 29 responden yang memiliki pola makan buruk, 8 responden (22,85\%) mengalami jarang kekambuhan nyeri dan 21 responden $(60,01 \%)$ sering mengalami kekambuhan.

Tabel 6. Hasil Analisis Data Bivariat Menggunakan Uji Chi-Square

\begin{tabular}{|c|c|c|c|c|c|}
\hline & Value & $\mathrm{df}$ & $\begin{array}{l}\text { Asymp. Sig. } \\
\text { (2-sided) }\end{array}$ & $\begin{array}{l}\text { Exact Sig. (2- } \\
\text { sided) }\end{array}$ & $\begin{array}{l}\text { Exact Sig. (1- } \\
\text { sided) }\end{array}$ \\
\hline Pearson Chi-Square & $10.862^{a}$ & 1 & .001 & & \\
\hline Continuity Correction ${ }^{\mathrm{b}}$ & 8.054 & 1 & .005 & & \\
\hline Likelihood Ratio & 12.949 & 1 & .000 & & \\
\hline Fisher's Exact Test & & & & .002 & .002 \\
\hline $\begin{array}{l}\text { Linear-by-Linear } \\
\text { ation }\end{array}$ & 10.552 & 1 & .001 & & \\
\hline $\mathrm{N}$ of Valid Cases & 35 & & & & \\
\hline
\end{tabular}


Hasil analisis data menggunakan uji chi square didapatkan hasil bahwa $p$ value $=0,005$. Ketentuan adanya hubungan pada uji chi square jika nilai $\mathrm{p}$ $\leq a$, ketentuan nilai $a=0,05$. Pada penelitian ini hasil $p \leq a(0,005 \leq 0,05)$. Jadi, hasil analisis data statistik didapatkan bahwa ada hubungan antara pola makan dengan frekuensi kekambuhan gout di Poliklinik Rumah Sakit Pertamedika Ummi Rosnati Banda Aceh.

\section{PEMBAHASAN}

Berdasarkan usia respondenpada penelitian didapatkan sebagian besar berada kelompok umur yaitu 51-60 tahun. Hasil ini sesuai dengan penelitian Chayani yang melaporkan bahwa sebagian besar penderita gout berada pada kelompok usia 45-59 tahun (Cahyani et al., 2019).

Berdasarkan penelitian ini didapatkan jenis kelamin paling sering mengalami kekambuhan gout artritis dari responden adalah laki- laki ya itu 18 orang $(51,4 \%)$ dan perempuan 17 orang $(48,6 \%)$. Sesuai dengan penelitian Batunadua dari 13 responden mayoritas yang berjenis kelamin laki-laki sebanyak 8 orang $(61,5 \%)$ dan minoritas yang berjenis kelamin perempuan sebanyak 5 orang $(15,4 \%)$. Jenis kelamin merupakan salah satu faktor resiko dari gout artritis.

Berdasarkan tingkat pendidikan terkahir, yang tergolong dalam kategori pendidikan rendah (tidak sekolah, SD, SMP, dan SMA ) sebanyak 25 responden $(71,4 \%)$. Hasil ini sesuai dengan penelitian Jaliana melaporkan bahwa terdapat 67 orang $(54,9)$ yang berpendidikan rendah (Jaliana, 2018). pendidikan rendah berhubungan dengan Pengetahuan Gout Artritis, semakin baik pengetahuan seseorang tentang kejadian Gout Artritis maka semakin tinggi tingkat kewaspadaannya sehinggamemperkecil angka kekambuhan Gout Artritis(Syarifah et al., 2019).
Berdasarkan penelitian ini didapatkan jumlah penghasilan sebagian besar kurang dari 2.900.000/bulan $(57,1 \%)$. Dalam penelitian Susanti didapatkan pendapatan paling banyak yaitu pada kelompok < Rp. $1.800 .000 /$ bulan. Daya beli pangan dalam rumah tangga tergantung dari tingkat pendapatan dan harga pangan. Semakin tinggi pendapatan, maka pola konsumsi semakin beragam. Pendapatan yang kecil bisa mengakibatkan minimnya variasi makanan yang dikonsumsi, hal ini akan berbahaya dan dapat meningkatkan kekambuhan gout (Susanti, 2016).

Berdasarkan karakteristik data pekerjaan responden. Sebagian besar responden berstatus sebagai ibu rumah tangga 12 responden (34,3\%). Rata-rata kegiatan yang dilakukan oleh ibu rumah tangga kebanyakan melakukan aktivitas fisik ringan daripada melakukan aktivitas berat. Sesuai dengan penelitian dari Cahyani yang membahas tentang aktivitas fisik pada penderita gout artritis. Melaporkan bahwa kurangnya aktivitas yang dilakukan dapat memicu responden untuk meningkatkan frekuensi kekambuhan gout (Cahyani, Surachmiet al., 2019).

Distribusi pola konsumsi makanan tinggi purin berdasarkan hasil penelitian ini didapatkan bahwa sebanyak 29 pasien $(82,9 \%)$ memiliki pola makan buruk dan 6 pasien $(17,1 \%)$ memiliki pola makan baik. Hasil ini sejalan dengan penelitian (Toto) terdapat $(57,1 \%)$ orang yang memiliki pola makan yang tidak baik dan $(42,9 \%)$ orang yang memiliki pola makan yang baik, penelitian ini dilakukan di RSUD Toto Kabila Kabupaten Bone Bolango.(Toto, dan Bolango, 2015). Oga melaporkan terdapat (82\%) penderita gout yang kurang baik pola makannya, penelitian ini dilakukan, Puskesmas Tinoor Kecamatan Tomohon Kota Tomohon (Oga, et al.,2017).

Penelitian ini menunjukan hasil bahwa lebih banyak responden yang memiliki frekuensi kekambuhan gout 
dalam kategori sering yaitu 21 orang $(60,0 \%)$ dibandingkan dengan kategori $(40,0 \%)$. Penelitian ini sesuai dengan penelitian Silvia didapatkan bahwa sebagian besar prevalensi kekambuhan pada penderita artritis gout di RSUD dr. H. Bob Bazar SKM Kalianda Lampung Selatan termasuk kategori sering yaitu sebanyak 20 orang $(54,1 \%)$ (Silvia, 2016).

Hasil analisis data menggunakan uji chi square didapatkan hasil bahwa $p$ value $=0,005$. Ketentuan adanya hubungan pada uji chi square jika nilai $p$ $\leq a$, ketentuan nilai $a=0,05$. Pada penelitian ini hasil $p \leq a(0,005 \leq 0,05)$. Jadi, hasil analisis data statistik didapatkan bahwa adanya hubungan antara konsumsi makanan tinggi purin dengan frekuensi kekambuhan gout di Poliklinik Rumah Sakit Pertamedika Ummi Rosnati Banda Aceh. Hasil penelitian ini sejalan dengan penelitian yang telah dilakukan Oga dengan nilai statistik menggunakan uji chi square memiliki nilai signifikan $a=0,05$ sementra nilai $p=0,003$ dengan responden sebanyak 46 orang sehingga dapat disimpulkan $\mathrm{p}<\mathrm{a}$ dengan demikian menunjukan bahwa terdapatnya hubungan signifikan antara pola makan dengan kejadian gout artritis pada lansia di Puskesmas Tinoor Kecamatan Tomohon Utara kota Tomohon(Oga, 2017). Hasil penelitian ini tidak sejalan dengan hasil penelitian yang dilakukan oleh Songgigilan (2015) di Puskesmas Ranotana weru bahwasannya tidak ditemukan hubungan yang signifikan antara pola makan dengan pengaruh kadar asam urat didalam darah pada penelitian ini didapatkan $p=0,000$ dengan jumlah responden sebanyak 93 penderita gout artritis(Songgigilan dan Kundre, 2019).

Gout artritis merupakan inflamasi sendi yang disebabkan oleh penumpukan kristal urat di cairan sendi dan jaringan disekitarnya. Asam urat merupakan produk akhir dari pemecahan purin normal yang terdapat di dalam asam frekuensi kekambuhan yang jarang

nukleat sebagai penyusun DNA dan RNA. Selain itu purin juga berasal dari makanan sebagai sumber eksogen . Jenis makanan yang mengandung banyak purin seperti hati, Paru, ginjal, jantung, sarden, sosis, otak bebek, burung, babat kacang polong dan biji melinjo(Kaneko et al., 2014).Purin yang terdapat di dalam makanan berasal dari protein yang dipecahkan. Konsumsi makanan dengan kandungan tinggi purin akan menyebabkan purin teroksidasi menjadi asam urat. Kemudian mengendap di dalam darah yang selanjutnya dibawa ke ginjal untuk dikeluarkan bersamaan urin. Asam urat merupakan produk yang sangat sulit larut dalam air dan mudah larut di dalam urin sehingga meningkatkan kerja ginjal untuk mengekskresikannya. ketika ambang batas kerja ginjal terlampaui menyebabkan kadar asam urat dapat mengendap didarah hiperurisemia(Isselbacher, et al.,2000). Hiperurisemia yang tidak ditangani dengan benar akan menyebabkan pengkristalan purin dan batu karang (tofus) yang sering terjadi di daerah sendi, tendon dan jaringan di sekitarnya sendi yang paling sering terkena adalah MTP-1 hal ini bisa disebabkan karena aliran darah vena yang tidak mampu memobilisasi purin dengan baik karena dipengaruhi oleh gaya gravitasi sehingga memudahkan terbentuknya kristal dilokasi tersebut. Kristal tersebut akan memicu reaksi peradangan disekitar sendi. sehingga menimbulkan rasa nyeri,bengkak, merah ,panas, dan kesulitan untuk beraktivitas. Oleh sebab itu konsumsi makanan dengan kandungan purin yang tinggi sangat berhubungan memicu kekambuhan gout artritis (Sumariyono dan Alwi, 2018).

\section{KESIMPULAN}

Berdasarkan hasil penelitian dan pembahasan tentang hubungan 
konsumsi makanan tinggi purin terhadap kekambuhan gout artritis di poli klinik penyakit dalam RS Pertamedika Ummi Rosnati Banda Aceh. karakteristik responden di poli klinik penyakit dalam RS Pertamedika Ummi Rosnati Banda Aceh yaitu sebagian besar berusia 51-60 tahun sebanyak 13 orang $(37,1 \%)$ berjenis kelamin laki-laki selain itu sebanyak 18 orang $(57,1 \%)$ pendidikan terakhir yang paling banyak adalah SMA sebanyak 13 orang $(37,1 \%)$. Pendapatan responden kurang dari UMR $(<2.900 .000)$, sementara profesi pekerjaan yang paling banyak adalah ibu rumah tangga (34,3\%).pola makan pasien gout artritis di poliklinik penyakit dalam RS Pertamedika Ummi Rosnati Banda Aceh didapatkan hasil 29 orang $(82,9 \%)$ dalam kategori buruk dan 6 orang $(17,1 \%)$ dalam kategori baik.frekuensi kekambuhan gout di poliklinik penyakit dalam RS Pertamedika Ummi Rosnati Banda Aceh didapatkan hasil 14 orang $(40,0 \%)$ dalam kategori jarang dan 21 orang $(60,0 \%)$ dalam kategorisering. $\mathrm{p}$ value $=$ 0,005 . Ketentuan adanya hubungan pada uji chi square jika nilai $p \leq a$, ketentuan nilai $a=0,05$. Pada penelitian ini hasil $p$ $\leq a(0,001 \leq 0,05)$. Jadi, hasil analisis data statistik diapatkan bahwa ada hubungan antara konsumsi makan tinggi purin terhadap kekambuhan gout artritis di Poliklinik Rumah Sakit Pertamedika Ummi Rosnati Banda Aceh.

\section{SARAN}

Penelitian ini diharapkan dapat memberikan masukan kepada rumah sakit untuk dapat meningkatkan mutu pelayanan terutama dalam menangani kekambuhan penyakit gout, mengedukasi pasien tentang komplikasi penyakit apabila terus diabaikan oleh responden, dan mengedukasi bagaimana cara pencegahan yang baik agar frekuensi kekambuhan gout berkurang. Selain itu skrining penyakit gout setiap bulannya dan memantau pola makanan yang dikonsumsi oleh penderita gout artritis. Penelitian ini diharapkan dapat menjadi sumber rujukan, serta diharapkan dalam penelitian selanjutnya dibahas mengenai porsi dari makanan yang dikonsumsi, menggunakan jumlah responden yang lebih banyak, serta menggunakan teknik random sampling dan menggunakan pendekatan secara cohort.Penelitian ini diharapkan dapat memberikan informasi bagi pasien dan keluargannya untuk selalu mengatur dan menjaga konsumsi makanan yang baik serta jumlah makanan yang sesuai kebutuhan dan dianjurkan untuk penderita gout artritis. Selain itu diharapkan pasien dan keluarga dapat mencatat porsi makan penderita untuk memudahkan dokter dan perawat mengevaluasi penyebab kekambuhan gout artritis.

\section{DAFTAR PUSTAKA}

Cahyani, F. D., Surachmi, F.et al .(2019) 'Effect on The Decrease Intensity Gymnastics Rheumatic Pain'. Jendral Nursing Journal, 3(2): 8997.

Isselbacher, Braunwald, et al.(2000) Harrison Prinsip-Prinsip IImu Penyakit Dalam. 13th edn. Jakarta: EGC.

Jaliana .(2018) 'Faktor-Faktor Yang Berhubungan Dengan Kejadian Asam Urat Pada Usia 20-44 Tahun Di RSUD Bahteramas Provinsi Sulawesi Tenggara Tahun 2017'. Jurnal Ilmiah Mahasiswa Keshatan Masyarakat, 3(2):1-13.

Kaneko, K. et al. (2014) 'Total purine and purine base content of common foodstuffs for facilitating nutritional therapy for gout and hyperuricemia', Biological and Pharmaceutical Bulletin, 37(5):709-721. doi: 10.1248/bpb.b13-00967.

Mei, C. L. et al. (2017) 'Chinese multidisciplinary expert consensus on the diagnosis and treatment of hyperuricemia and related diseases: Multidisciplinary expert 
task force on hyperuricemia and related diseases', Chinese Medical Journal, 130(20): 2473-2490. doi: 10.4103/0366-6999.216416.

Metabolism, N. A. (2012) 'Essence of the Revised Guideline for the Management of Hyperuricemia and Gout', 140(2):324-329.

Neogi, T. et al. (2015) '2015 Gout classification criteria : an American College of Rheumatology / European League Against Rheumatism collaborative initiative', the American College of Rheumatology and the European League Against Rheumatism, 74(208237):1789-1798. doi: 10.1136/annrheumdis-2015208237.

Oga, C. (2017) 'Hubungan Pengetahuan Dan Pola Makan Dengan Kejadian Gout Artritis Pada Lansia Di Puskesmas Tinoor Kecamatan Tomohon Utara Kota Tomohon', Buletin Sariputra, 7 (3):31-32.

Price, A. Sylvia, Wilson, M. L. (2006) Patofisiologi Konsep Klinis ProsesProses Penyakit. 6th edn. Jakarta: Buku Kedokteran EGC.

Silvia, E. (2016) 'Hubungan Tingkat Pengetahuan Sikap Dan Perilaku Diet Terhadap Angka Kekambuhan Pada Penderita Artritis Gout di Poli Penyakit Dalam RSUD DR.H.Bob Bazar Skm Kalianda Lampung Selatan Tahun 2016', 25.
Songgigilan, A. M. G. dan Kundre, R. (2019) 'Hubungan Pola Makan Dan Tingkat Pengetahuan Dengan Kadar Asam Urat Dalam Darah Pada Penderita Gout Artritis di Puskesmas Ranotana Weru', ejournal Keperawatan (e-Kp), $7(1): 1-8$.

Sumariyono dan Alwi, I. (2018) Pedoman Diagnosis dan Pengelolahan Gout, Perhimpunan Rheumatologi Indonesia. Jakarta: Perhimpunan Reumatologi Indonesia.

Susanti, N. M. D. (2016) 'Hubungan antara Pengetahuan dan Sosial Ekonomi dengan Penyakit Gout Artritis pada Lansia di Wilayah Kerja Puskesmas Lawanga': 2432.

Syarifah, N. Y. et al. (2019) 'Gambaran penderita penyakit asam urat di dusun karanglo sidomoyo godean sleman yogyakarta'. Majalah IImu Keperawatan dan Kesehatan Masyarakat,8(2):85-90.

Tumenggung, I. (2015) 'Hubungan pola Makan dengan Kejadian Gout Artritis di RSUD Toto Kabila Kabupaten Bone Blango. Health and Nutritions Journal, 1:6-9.

Widyanto, F.W.(2017) 'Artritis Gout Dan Perkembangannya', Saintika Medika, 10(2):145-147. doi: 10.22219/sm.v10i2.4182. 